\title{
Influence Of Family Partnership Model In Preconception Period With Partnership Approach Towards Pregnancy Preparedness
}

\author{
Yulizawati ${ }^{1}$, Detty Iryani ${ }^{2}$, Lusiana Elsinta Bustami ${ }^{3}$, Aldina Ayunda Insani ${ }^{4}$ Alief Duha ${ }^{5}$ \\ \{yulizawati@med.unand.ac.id ${ }^{1}$, detyani@yahoo.com², lusianaelsinta@med.unand.ac.id ${ }^{3}$, \\ aldinaayundainsani@med.unand.ac.id $\left.{ }^{4}\right\}$ \\ Universitas Andalas, Indonesia ${ }^{1,2,3,4}$ \\ Jichi Medical School of Medicine, Japan ${ }^{5}$
}

\begin{abstract}
The high growth rate of the population is expecting that the 2045 gold generation can be achieved with good family planning and good quality generation so that the health services not only focus on curative and rehabilitative but also on promotive and preventive. The aims are every couple at fertile age who plan to get married and make a family should have good planning in every aspect of life so that the 8 (Eight) basic functions of the family can be done well so they could create proper families. Methods of this study use quantitative design with intervention in the form of partnership and evaluation. There are 2 groups which are the intervention group and the control group. The results showed that there were differences regarding knowledge of couple about ovulation during pregnancy, family support and nutrition, before and after partnership $(\mathrm{p}=0.000)$. No difference regarding knowledge of couple about psychological readiness before and after mentorship. The International Confederation of Midwifery states that midwives as responsible and accountable professionals work in partnership with women to provide support, care, and counsel during pregnancy, labor and the postpartum period, to conduct births of the midwives themselves, provide care for newborns and baby. It is hoped that there is religious affairs office collaborative program with the midwife in preparing the couples for the preconception period regarding religion and health.
\end{abstract}

Keywords: Partnership, Preconception, Partnership.

\section{Introduction}

The high growth rate of the population itself is expecting that the golden 2045 generation can be achieved with good family planning and quality generation so that health services not only focus on curative and rehabilitative but also on promotive and preventive. In the end, it will reduce the burden of the state towards the achievement of UHC 2019. With the optimization of professional roles and all related field, it is hoped that there will be cooperation in crossprogrammed cooperation and can be duplicated in every region in Indonesia. The purpose of this study is for each couple at a fertile age can plan the family well. This study uses quantitative design with intervention in the form of counseling and evaluation. There are 2 groups which are the intervention group and the control group.

The research objectives are every couple at fertile age who will marry and form a family should have good planning in every aspect of life so that 8 (Eight) main function of the family 
can be done well so as to create proper families. (1) Couples can determine when the wife ovulates so they can plan whether to get pregnant soon or delay pregnancy. (2) Couples can prepare for pregnancy at least 3 months before so they know and aware what kind of needs for the wife to be met such as the nutrients needed and what foods should be avoided. (3) Couples are ready for physical, psychological, social, spiritual and cultural changes that will occur during the pregnancy process. (4) Ensure easy access by couples in dealing with role change in their lives. (5) Provides up to date information for the family.

\section{Material and Methods}

This study uses quantitative design with intervention in the form of counseling and evaluation. There are 2 groups which are the intervention group and the control group. Bivariate analysis is categorical correlative by using a t-test, to test the hypothesis with Mc. Nemar, multivariate analysis by using logistic regression. The study population is fertile couples in the Work Area of Padang Selatan District.

The sample is a partial or representative of the population under study. Based on the statistical approach, the sample size is determined by the statistical model to be used to test the hypothesis. In this study, the statistical test that will be used is $t$-test for paired data by using Mc. Nemar. The sample was taken by using purposive sampling totaling 60 people.

\section{Results}

The study result "Influence of Family Mentorship Model in Preconception Period with Partnerships Approach and Interprofessional Education towards Pregnancy Preparedness". The study that carried out by noting any changes, complaints and needs and interviews and using questionnaire was conducted in June - October 2017 to 78 couples. All couples are given pretest and family mentorship in preconception periods with partnerships and interprofessional education approach towards pregnancy preparedness. Then conducting posttest to know the influence of model which have been done.

After collecting the data, then the data is processed and analyzed by using SPSS software tool which is univariate, bivariate and multivariate data analysis. The results are presented in the form of frequency distribution tables and cross tables and given narrative descriptions in order to provide clear information about the study results. The results of this study are as follows:

\subsection{Overview of Study Location}

This study was conducted in all religious affairs office in Padang city for all couples who are enrolling for marriage. Each religious affairs office is lead by a head and every bride and groom will be assigned to get a religious explanation regarding marriage. Studyers get permission from each head of RELIGIOUS AFFAIRS OFFICE to conduct this study by assisting regarding health, namely assistance of partnership and interprofessional education in the preconception period. 


\subsection{Analysis Results}

The analysis was performed using univariate and bivariate. The results can be seen in table 1:

Table 1. Influence of Family Mentorship Model in Preconception Period by Partnerships Approach and Interprofessional Education Towards Pregnancy Preparedness.

\begin{tabular}{llllll}
\hline \multirow{2}{*}{ Variables } & \multicolumn{2}{l}{ Before Assistance } & \multicolumn{2}{l}{ After Assistance } & $\rho$ value \\
\cline { 2 - 6 } & $\mathrm{f}$ & $\%$ & $\mathrm{~F}$ & $\%$ & \\
\hline Ovulation Period & 51 & 65.4 & 52 & 66.7 & 0.000 \\
Family Support & 62 & 79.5 & 55 & 70.5 & 0.030 \\
Psychological Readiness & 57 & 73.1 & 60 & 76.9 & 0.120 \\
Nutrition & 59 & 75.6 & 52 & 66.7 & 0.000 \\
\hline
\end{tabular}

Based on the above table, it is shown that there is an influence of the mentoring model with the knowledge level of the couple about ovulation $(\mathrm{p}=0.000)$, about family support $(0.030)$ and nutrition (0.000) $(\mathrm{p}=0.120)$.

\section{Discussion}

Based on Table 1 show that there is an influence of the mentoring model with the knowledge level of a couple about ovulation $(\mathrm{p}=0.000)$, about family support $(0.030)$ and nutrition (0.000) during pregnancy, but there is no effect of the mentorship model with psychological readiness $(\mathrm{p}=0.120)$.

Mentoring models with women (partnerships), communities and with other service providers may involve the Information and Communication Technology (ICT). By using new platforms and technologies, it can bring midwife closer to women, Interdisciplinary collaboration and educational, developing midwife competencies as well as increasing the scope of practice that allows for the fulfillment of preconceptional needs (Renfrewetal, 2014).

The International Confederation of Midwifery states that midwives as responsible and accountable professionals work in partnership with women to provide support, care, and counsel during pregnancy, labor and the postpartum period, to conduct births of the midwives themselves, provide care for newborns and baby. These treatments include preventive measures, promotion of normal delivery, detecting complications and accessing medical care or other appropriate assistance and implementing emergency measures.

The existence of partnerships with women is a strategic effort for a very important commitment towards our goals. The partnership model encourages engagement with civil society, government, professional health organizations and the private sector in promoting the health of women, newborns, and their families. Successful national, regional and international partnerships have resulted in increased influence, wider range, combined credibility, knowledge sharing, skills and effective use of resources. With a sustainable long-term partnership can plan into the future for innovation and sustained success. Ultimately this partnership can advocate women in midwifery services.

For all that, it is also supported by Inter-professional education, which is a learning process that occurs when two or more professions learn from one to another to improve the quality of service. (Endang Lestari in Lorente et al., 2006) 
WHO in its framework explains that the goal of the interprofessional education framework recommendation and collaborative practice is to provide strategies and ideas that assist policymakers in implementing each element within this framework so that the ultimate goal of strengthening the health system and increasing health outcomes can be achieved (WHO, 2013).

A survey conducted by the WHO from February to May 2008 including 42 countries with 396 respondents on their perceptions regarding interprofessional education programs $(50.4 \%)$ supported the integration of IPE in the educational curriculum and as many as $46,9 \%$ of students in developed countries and $36.8 \%$ of students in developing countries are assessed in groups with other health professionals (WHO, 2013).

Hammick M et al. in 2007 also concluded that interprofessional education had been well received because it can improve knowledge and skills in collaborative practice. However, staff development is an important key in the effectiveness of interprofessional education, and all healthcare professionals who are actively involved in IPE can bring about the uniqueness of the value of each profession (Hammick et al., 2007). Earlier in his book, Freeth et al. have also explained that the greatest challenge of the implementation of interprofessional education is how to develop, conduct, and evaluate during the process to improve health care system (Freeth et al., 2005).

In ICM Triennial Congress in Prague 2014 it is also reported that a midwife must be able to form a global policy whereby the goal is to raise awareness of midwives and expand the influence of midwives who aim to advocate for policy changes in relation to maternal, child and reproductive health services. It also aims to state that midwifery needs to be strengthened through collaboration with colleagues aiming to strengthen teamwork to improve public health status and share vision to improve health promotion for mothers and families in providing support in every health program (ICM, 2014).

Based on our data we suggest (1) It is needed for cross-program and cross-sectoral cooperation in the preparation of a family. (2) Increasing education for WUS in determining ovulation period. (3) Conducting programmed properly. (4) It is hoped that other approach models can be applied together with partnership and interprofessional education so that readiness of the couple for the preconception period is more optimal. (5) It is hoped that there is religious affairs office collaborative program with the midwife in preparing the couples for the preconception period concerning religion and health.

\section{Conclusion}

1. There is a difference between knowledge of couple about ovulation during pregnancy before and after counseling $(\mathrm{p}=0.000)$

2. There is a difference between knowledge of couple about family support before and after counseling $(\mathrm{p}=0.030)$

3. There is no difference between knowledge of couple about psychological readiness before and after counseling $(\mathrm{p}=0.120)$

4. There is a difference of knowledge level regarding nutrition of couple before and after counseling $(\mathrm{p}=0.000)$

5. There is influence of family mentoring model in preconception period with partnerships approach and interprofessional education toward pregnancy readiness that is ovulation period $(\mathrm{p}=0.000)$ 
6. There is influence of family assistance model in the preconception period with approach of partnerships and interprofessional education to pregnancy preparedness that is family support $(\mathrm{p}=0.030)$

7. There is no influence of family assistance model in the preconception period with approach of partnerships and interprofessional education toward pregnancy preparedness in terms of psychological preparedness $(p=0.120)$

8. There is influence of family mentoring model in the preconception period with partnerships and interprofessional education approaches to pregnancy preparedness ie nutrition $(\mathrm{p}=0.000)$.

\section{References}

[1] Somov, A.: Judul artikel. Prosiding IOP mengenai Pemrogram Komputer. pp. 1-11 (2011)

[2] Motaz, A.: Pengenalan Pemrograman Web. Vol. 2, pp. 10-11. Penerbit A, Indonesia (2013)

[3] Somov, A.: Judul artikel. Jurnal ABCD. pp. 1-11 (2011)

[4] Department for.: International Development. Scaling Up Nutrition: The UK's position paper on under-nutrition, UKAID, London (2011)

[5] Freeth D, Hammick M, Reeves S, Koppel I, Barr H.:Effective interprofessional education. UK: Blackwell Publishing Ltd(2005)

[6] Furber C, Hickie J, Lee K, McLoughlin A, Boggis C, Sutton A, Cooke S, Wakefield A.: Interprofessional education in midwifery curriculum: the learning through the exploration of the professional task project (LEAPT). Elsevier Journal.pp. 358-66 (Dec 2004)

[7] Hammick M, Freeth D, Koppel I, Reeves S, Barr H.:A Best Evidence Systematic Review of Interprofessional Education Medical Teacher. US: Best Evidence Medical Education (BEME) Collaboration (2007)

[8] International confederation of midwives.., Essential competencies for basic midwifery practice, ICM (2013)

[9] International confederation of midwives.:Core Document Philosophy and Model of Midwifery Care, ICM (2012)

[10] International confederation of midwives.:A promising future,Strategic directions 2014-2017, ICM. (2013)

[11] International Confederation of Midwives. Triennial Report 2011 - 2014. Diunduh tanggal 29 Agustus 2014. Tersedia dari URL http://www.internationalmidwives.org

[12] Midwifery 2020 Programme. Midwifery 2020.:Delivering Expectations. Cambridge: Jill Rogers Associates. (2010)

[13] Nisbet,Gillan dkk. Interprofessional Health Education". (Online) . (http://www.health.wa.gov.au/wactn/docs/IPEAUSlitreview2011.pdf), Diakses 22 Desember 2014

[14] Peraturan rektor Universitas Andalas No 8 tahun 2009 tentang Peraturan Akademik Program Sarjana Universitas Andalas. (2009)

[15] Perpres RI No 42 tahun 2013 tentang Gerakan Nasional Percepatan Perbaikan Gizi. (2013)

[16] Petra ten Hoope. Et all.: Midwifery 2030:a woman's pathway to health, Elsevier. (2016)

[17] World Health Organization.:Framework for action in interprofessional education and collaborative practice. Geneva: WHO Press, World Health Organization. Diunduh pada tanggal 5 Oktober 2014. Tersedia pada URL http://whqlibdoc.who.int/HQ/2010/WHO_HRH_HPN_10.3_eng.pdf

[18] World Health Organization.2014. Interprofessional education case study. Geneva: WHO Press. World Health Organization. Diunduh pada tanggal 28 September 2015. 